www.jmscr.igmpublication.org

Impact Factor 5.84

Index Copernicus Value: 71.58

ISSN (e)-2347-176x ISSN (p) 2455-0450

crossref DOI: _https://dx.doi.org/10.18535/jmscr/v5i9.23

\title{
Journal Of Medical Science And Clinical Research

\section{Clinical study of Ghritkumari (Aloe-vera) and Kakamachi (Solanum nigrum) in Kamala roga (Jaundice)}

\author{
Authors \\ Dinbandhu Kumar Kanavjiya ${ }^{1}$, Dr Vijay Shankar Dubey ${ }^{2}$, \\ Dr Amrendra Kumar Singh ${ }^{3}$ \\ ${ }^{1}$ MD (Ay), AMO, GGSH., Patna, 7004898087 \\ ${ }^{2}$ Prof. Dravyaguna Dept.,Govt. Ayurveda college Patna \\ ${ }^{3}$ Asso. Prof., Rog evam Vikriti Dept., Govt. Ayurveda College Patna
}

According to Indian philosophical traditions it is believed that Ayurveda has a divine origin that is, it has been created by Brahma the creator of universe and has been transmitted to various saints and scholars to remove the sufferings and miseries of all living subjects throughout the world. The present study entitled "Gunakarmatmak study of Ghritkumari (Aloe vera) and Kakamachi (Solanum nigram) with special reference to Kamala (Jaundice)" has been under taken to launch a literary and clinical study of Kamala (Jaundice) along with therapeutic evaluation of the efficacy of Ghritkumari leaf and Kakamachi Panchang churna in patients of Kamala. Ayurveda is really well known for it simple, promotive, preventive, curative and holistic approach. Ghritkumari and Kakamachi which are very useful Ayurvedic drug, one of the most easily available, popular, widely utilized and described by all ancient Acharyas like Charaka, Sushruta, Vagbhata and all Nighantukars has been selected for the present research work. Here, the drug Ghritkumari and Kakamachi has been comprehensively evaluated by all aspects regarding it.

\section{Drug Review Historical Background}

Aloe vera: In the foremost eve written document of knowledge, we cannot trace any reference regarding the drug Kumari. In Bhela Samhita, Kumari is mentioned as an ingredient of a compound in the treatment of Vata Vyadhi. There is no any reference found in Brihatrayi. In Sharanghadhara Samhita, its use is described in Pliha Roga. All Nighantu Kalas have mentioned Kumari in different Vargas. In 1932 it was included in British pharmacopoeia. But in Ayurvedic amenities there is no any direct reference of Kumari regarding as Yuvanapidika. Kakamachi: It is not mentioned in the Vedic literature. In Charaka Samhita references regarding Kakamachi is present in Sutrasthana, Nidanasthana, Vimanasthana and also Chikitsasthana. Kakamachi is highlighted for its Kustaghna property, in Charaka sutrasthana 3/16. Again in Atryebhadrakapyeeya adhyaya - 84 sloka, Charaka mentions Kakamachi in the context of Virudha aharas by saying that, Kakamachi used after a long time, after cooking is Virudha. Aloe vera- About 14 synonyms have been traced regarding Ghritkumari in various 
samhita granths and Nighantus. The synonyms of Ghritkumari to morphological characters in correlation with that of botanical description of the plant Aloe vera. The synonyms like Ghritkumari, Kumari, Grhakanya, Visala, Mndala, Bahuptra etc. indicate the morphological characters. Kakamachi- As well as synonyms of Kakamachi are Kakamata, Gudaphala, Kakini, Vara, Sundari, and Gucchaphala etc. Rasapancaka: ALOE VERA- According to Ayurvedic pharmacology, the drug is based on Rasa Pancaka viz. Rasa, Guna, Virya, Vipaka and Prabhava. In Brhatrayi Acaryas stated that some of the drug act is accordance with their taste, some with properties, some with potency, some with post digestive effect and some with specific action. (Ch. Su. 26/17, Su. Su.40/17, AS.Su. 17/30). Ghritkumari has been established Guru, Snigdha, Pichila in Guna; Tikta and Madhura in Rasa; Katu in Vipaka, sita in Virya. According to Doshaghnata it is Tridosasamakka. KAKAMACHI- Kakamachi has been established Laghu, Snigdha in Guna; Tikta in Rasa; Katu in Vipaka, Anusna in Virya. According to Doshaghnata it is Tridosaghna.

Therapeutic Actions: Aloe vera: Kumari has been important and potent drug in ancient medicine and therapeutics finding its uses in several diseases as mentioned in different classical texts dealing with clinical management. Kamala (jaundice) by Bhavaprakasha, Pandu (anemia) Due to pharmacological actions on liver and spleen. Juice of Kumari is given in Yakrta and Pliha vrddhi and roga. Due to potent cholagogue (Pittanirharana, Pittarecana). The juice of Kumari mixed with Haridra (turmeric) powder is given in spleen enlargement or Plihavrddhi. by Sharangadhara Samhita. Rajoabrodha (amenorrhea) Kumarikavati and Rajah pravartani vati are prescribed in menstrual problems as emmenagogue drugs.by Bhaishajya Ratnavali. Extract of Kumari leaves juice (Kanyasara) is given. Varna (wound) and abscess Kumari mixed with tila and sour gruel or alone is applied to ripens the abscess. Kumari leaves or juice is recommended to apply over abscess and wounds in ama and pacyamana stages for attaining pakva condition of vidradhi and vrana. by Vaidya Manorama. Leaves pulp of Kumari are prescribed to externally apply over or by covering up with the steamed leaves devoid of pulp, in all stages of abscess as indicated in medical texts. by Vidradhi cikitsa context Kakamachi:- It is told that Kakamachi is Tridoshashamaka, Snigdha, Ushna, Tikta, Rasayani, Swarya, Vrushya etc. and acts against Yakrita viridhi, Shotha, Kusta, Arsha, Jvara, Meha, Hikka, Chadri, and Hrudroga.

Therapeutic Indication- Ghritkumari is mostly indicated in the diseases like Agnidagdha, Raktavikarashotha, Dourbalya, Krmirogatantukrimi, Yakrtplihavikara vriddhi, PanduKamala Modern authors indicate it in, Jaundice, Anticancer activity, cough drops, Analgesic: Antiinflammatory activity etc. CULTIVATION: Soil: Naturally occurs in driest and poorest soils and can be grown in variety of soil. But the most ideal soil for its sandy loam that is slightly alkaline with a PH up to 8.5.Theroot system of this plant is shallow and does not penetrate deep into the soil. However, water logged soil is totally unsuitable.

Pharmacognostical Study: Pharmacognostical study of plant drugs plays a major role in the standardisation and quality control of the plant drugs. The study of macroscopic and microscopic characters was carried out. Morphology: Aloe vera: A perennial and coarse looking plant is with a short, thick, cylindrical, simple, woody stem, 12 feet high, sending out at the base numerous stolons. Kakamachi: Herbs or shrubs, erect, trailing or scandent, rarely small trees. Leaves are alternate often in unequal pairs rarely clustered never truly opposite, entire, lobed or pinnate. Flowers regular hermaphrodite, terminal or lateral axillary or extraaxillary cymes or solitary or clustered pedicels.

Phytochemical Study: Phytochemical studies play a very important role in the standardization of any single or compound drug. The loss on drying, Ash Value, Water soluble extract and 
Disintegration time of Ghiritkumari and Kakamachi were of the standard level with comparison to Ayurvedic pharmacopoeia of India. Another data regarding UV spectra test and T.L.C. study of the sample are also compared with the same which is deeply discussed in the section of phytochemical study. As the phytochemical analysis of the Ghritkumari and Kakamachi could not be compared due to lack of comparative data in the absence of any previous study on it. But obtained data from the various test like, Refractive index, Specific gravity, Acid value, Iodine value and Saponification value of Ghiritkumari and Kakamachi would be helpful to analyzed and to standardize the drug for the next study. Different types of chemical constituents like Anthraquinones, Lignin, Saponins, Fatty acids, Salicylic acid, and Amino acids of Aloe vera. TLC results indicate Musabbar (Alua) Rf value of spots a visualized in UV $366 \mathrm{~nm}$ at Rf. 0.10, 0.30, 0.40, $0.60 \& 0.75$ ( 5 spots). Rf value of spots visualized in UV $254 \mathrm{~nm}$ at Rf. 0.24, 0.30, 0.40, 0.50, 0.55 \& $0.75(6) \mathrm{Rf}$ value of spots visualized after spray of sulphuric acid reagent and heated $110^{\circ} \mathrm{C}$ for 5 minuts at Rf. 0.20, 0.30, 0.55, 0.75 (4 spots). Leaves contain quercetin glycosides. Immature fruits contain gluco alkaloids. Leaves and fruits contain solasodine type compounds. Fruits contain steroidal glycosides, glycoalkaloids, $\alpha$ solamargine $\& \alpha$ - solasonine. Seeds contain fatty oil of Kakamachi. TLC results indicate Kakamachi $\mathrm{Rf}$ value of spots visualized in Iodine at $\mathrm{Rf} 0.10,0.30,0.40,0.60 \& 0.75$ (6 spots), Rf value of spots visualized in UV $254 \mathrm{~nm}$ at $\mathrm{Rf}$ $0.24,0.30,0.40,0.50,0.55 \& 0.75$ (6 spots) Rf value of spots Visualized after spray of sulphuric acid reagent and heated $110^{\circ} \mathrm{C}$ for 5 minuts at $\mathrm{Rf}$ $0.10,0.25,0.30,0.35,0.40,0.60,0.65,0.75 \&$ 0.85 (9 spots).

Disease review: 1. "Kayam malayte iti Kamala" It means the whole body becomes dirty, because of the accumulation of mala i.e. mala ranjaka pitta. 2 . Kama + La $=$ Kamala. Kamam Lati Hanti Iti Kamala. It means there is aversion for all desires in the patient of Kamala which may because of his physical and mental disability that is seen in this disease. "Kutsita mala yasmin Roga sah Kamala Roga." Regularly produced mala and its excretion from the body is essential phenomena maintain to the health. As this function has been enunciated by Charaka and Susruta. "Dosha Dhatu mala moolam hi shariram." The word Jaundice has been derived from the French word "Jaundice" which means yellow discolouration of the body organs. In Ayurveda similar nomenclature has been given for so many diseases on the basis of symptoms like Pandu, Prameha, and Atisara etc. But in the case of this disease they have preferred to name it as Kamala, which is based on pathogenesis. It is to indicate that in this disease, the whole body is highly vilated by male ranjaka pitta (Bilirubin) which is the by product of rakta dhatu. TYPES OF KAMALA: Many classification of kamala have been suggested by various authors. They have classified kamala in one way or the other way, as described in different Ayurvedic classics. Charaka has mentioned two types of kamala (Ch.Su.19/4). (1) Koshthashrita, (2) Shakhashrita Kamala. But only koshthashrita Kamala is a misnomer. In Kamala pitta roopa mala has to spread all over the body may be skin, eyes, mouth etc. So the word koshthashrita has been introduced in place of koshthashrita kamala and the same has been referred in Chikitsa sthana and other places. Of course shakhashraya Kamala is observed in rudhapatha kamala where due to obstruction of the biliary passages there is no pouring of pitta in Kamala so it means it gives rise to shakhashrita Kamala. The word shakha here refers to skin, rakta, mamsa etc. Thus appropriately the two types of Kamala should be referred as follows: (1) Koshthashakhashrita Kamala (2) Shakhashrita Kamala.

Clinical Study- The clinical study was carried out on 30 patients of Kamala (Jaundice), which were divided into 3 groups viz. Group I Application of Ghritkumari. Group II Application of Kakamachi. Group III Combined group. The patients were selected randomly irrespective of age, sex, marital status, Education etc. The observation and results 
obtained are discussed here. For the assessment of results of the therapy, the patients were examined subjectively. Signs and symptoms were assessed by adopting suitable scoring methods as mentioned in materials and methods. The results obtained were statically analyzed and mean change in \%, S.D, ' $t$ 'value, $p$ value were calculated for each criteria of assessment in all group.

Selection of patients: For the present study, patients fulfilling the clinical criteria for diagnosis of Kamala (Jaundice) were selected irrespective of their age, sex,religion etc, in random from O.P.D.and I.P.D.section of Govt.Ayurvedic College and Hospital, Kadam kuan, Patna.

Preparation of Drug: Drugs were prepared in Dravyaguna Pharmacy of Govt.Ayurvedic College and Hospital, Kadam kuan, Patna.

Incidences: 1. Age: Group I: Group I: Majority of the patients were of age group 21-40 yrs - 5 (50\%) followed by Gr. 41-60 yrs 4 (40\%), 12$20 \mathrm{yrs} 1(10 \%)$. Group II: Majority of the patients were of age grou Group II: p 21-40 yrs - 5 (50\%) followed by Gr. 12-20 yrs 3 (30\%), Gr. 41-60yrs $2(20 \%)$ Group III: Majority of the patients were of age group 21-40 yrs - 7 (70\%) followed by Gr. 12-20 yrs 2 (20\%), Gr. 41-60yrs - 1(10\%). Overall incidence of Majority of patients were of age Group 21-40yrs 17(56.66\%) followed by age Gr.41-60 yrs (23.33\%) and least in age group 1220 yrs(20\%).In present study maximum 17 patients out of 30 were between 21-40 yrs. (2) Sex : Group I: Group I: Group I: Majority of patients were male i.e. 8 (80\%) and female patients were 2 (20\%) Group II: Majority of patients were male i.e. 7 (70 Group II: \%) and female patients were $3(30 \%)$ Group III Majority of patients were male i.e. $7(70 \%)$ and female patients were $3(30 \%)$ (3) Marital status: Group I: Majority of patients were unmarried i.e. 9 Group I: (90\%) and married patients were $1(10 \%)$. Group II: Majority of patients were married i.e. 5 Group II: (50\%) and unmarried patients were 5 (50\%). Group III Majority of patients were married i.e. 5 (50\%) and unmarried patients were 5(50\%) However any consolidated conclusion may not be drawn from the findings of this data, even then $90 \%$ patients were unmarried and due this they were conscious about their outfit and reported in more number at the clinic. 4. Educational profile Group I Majority of patients had matric 7 (70\%), Group I patients with Graduate $2(20 \%)$, matric $1(10 \%)$, primary and illiterate $0(0 \%)$. Group II Majority of patients had Inter $3(30 \%)$, patients with Graduate 2 $(20 \%)$, primary $2(20 \%)$ and illiterate $2(20 \%)$. Primary $1(10 \%)$ Group III Majority of patients had Graduate $4(40 \%)$, Inter3 (30\%), patients with, matric $2(20 \%)$ and illitrate1 (10\%).Primary $1(0 \%)$ Though educational qualification does not have any direct effect on the occurrence of Kamala, it may be concluded that education creates awareness in the individuals to seek proper cure for their disorders and consult the physician specialized in the disorders by which they are suffering from. Matric the predominant age group was study period thus higher percentage (40\%) belongs to educational group. 5. Occupation Group I Majority of patients were businessman 4 (4 Group I 0\%), farmer 2 (20\%), House wife $2(20 \%)$, serviceman $1(10 \%)$ and student $1(10 \%)$. Group II - Majority of patients were student 4 (40\%), serviceman 2 (20\%), House wife 2(20\%), farmer 1(10\%) and businessman 1(10\%) Group III Majority of patients were student 5 (50\%), House wife $2(20 \%)$, businessman $2(20 \%)$, serviceman 1 (20\%), and farmer $0(0 \%)$ Almost all the types of occupational groups had the patients of Kamala where the highest number was recorded in the patients who were student farmer or Housewife. The over increasing tension of studies followed by averting sleep till late night for reading and due to constant worries, irregular food habits, over indulgence in sleep, addictions like tea, tobacco etc. aggravating the Vata and Pitta Doshas create Kamala in a long run. 6. Food Habitat:- Group I Majority of patients were nonvegetarian 8 Group I $(80 \%)$, and vegetarian 2(20\%). Group II Majority of patients were nonvegetarian $8(80 \%)$, and vegetarian 2(20\%). Group III Majority of patients were nonvegetarian $8(80 \%)$, and vegetarian 2 $(20 \%)$. This may show that Kamala is more 
common in non vegetarian. 7. Prakriti:- Group I Majority of patients were vatapitta 8 (8 Group I $0 \%)$, vatakapha $1(10 \%)$ and pittakapha $1(10 \%)$. Group II Majority of patients were vatapitta 7 (70\%), vatakapha $2(20 \%)$ and pittakapha 1(10 $\%)$. Group II Majority of patients were vatapitta 7 (70\%), vatakapha $2(20 \%)$ and pittakapha $1(10 \%)$. A maximum no. of patients belongs to Vata Pitta Prakriti $(73.33 \%)$ followed by vata Kapha Prakriti $(16.66 \%)$. Vata and Pitta and are the two main doshas, which play an important role in the occurrence of Kamala (jaundice). It may be concluded from this finding that when such individuals indulge in etiological factors they are more prone to have Kamala. Observations about prakriti are in accordance with textual references. 8. Kostha. Group I Majority of patients were krura 5 (50\%) Madhya 3 (30\%) and mridu 2(20\%). Group II Majority of patients were krura 7(70\%) Madhya $2(20 \%)$ and mridu 1(20\%). Group III Majority of patients were krura $7(70 \%)$ Madhya $3(30 \%)$ and mridu $0(0 \%)$ Maximum numbers of patients $(63.33 \%)$ were found Krura Kostha followed by Madhya Kostha $(26.66 \%)$. This also indicate the causatively of Vata and Pitta dominated Dwandvaja Prakriti may be responsible for Kamala. 9. S.Billirubin Group I Majority of patients were level of $>2-4$ is $4(40 \%)$ followed by level of 1 to 2 is $3(30 \%)$, and level of $>4-10$ is 3 $(30 \%)$. Group II Majority of patients were level of 1 to 2 is $7(70 \%)$ followed by level of $>2-4$ is 2 (20\%), and level of $>4-10$ is $1(10 \%)$. Group III Majority of patients were level of $>2-4$ is $4(40 \%)$ followed by level of 1 to 2 is $3(30 \%)$, and level of $>4-10$ is $3(30 \%)$. 10. S.G.P.T. Group I Majority of patients were level of $>35-100$ is $10(100 \%)$ followed by level of Up to 35 is $0(0 \%)$, and level of $>100$ is $0(0 \%)$.Group II Majority of patients were level of $>35-100$ is $7(70 \%)$ followed by level of Up to 35 is $2(20 \%)$, and level of $>100$ is $1(10 \%)$. Group III Majority of patients were level of $>35-100$ is $8(80 \%)$ followed by level of up to 35 is $0(0 \%)$, and level of $>100$ is $0(20 \%)$.

Clinical features: In the present clinical study the observation of various cardinal features in patients are as under. Yellowish discoloration eyes and urine, Loss of appetite, Abdominal pain, Nausea/Vomiting, Fever, Muscles cramp, Itching and Weakness.

\section{Effects of Therapy}

\section{(A)Effect on symptoms:}

1. Yellowish colour of eyes: Group I The mean grade of Yellowish colour of eyes before treatment was 2.3 and it lowered down to 0.5 with $\mathrm{SD} \pm 1.032$, giving a relief of $78.26 \%$ with ' $\mathrm{t}$ ' value $5.51 \quad(\mathrm{p}<0.001)$ which was statistically highly significant. Group II The mean grade of Yellowish colour of eyes before treatment was 2.4 and it lowered down to 0.6 with $\mathrm{SD} \pm 0.632$, giving a relief of $75 \%$ with ' $t$ ' value $9(\mathrm{p}<0.001)$ which was statistically highly significant. Group III The mean grade of Yellowish colour of eyes before treatment was 2.5 and it lowered down to 0.4 with $\mathrm{SD} \pm 0.316$, giving a relief of $84 \%$ with ' $t$ ' value $21 \quad(p<0.001)$ which was statistically highly significant.

2. Yellowish colour of urine: Group I The mean grade of Yellowish colour of urine lowered from 2.1 to 0.5 with $\mathrm{SD} \pm 0.843$ giving a relief of $76.19 \%$ with ' $\mathrm{t}$ ' value $6(\mathrm{p}<0.001)$ which was statistically highly significant. Group II The mean grade of Yellowish colour of urine lowered from 2.5 to 0.7 with $\mathrm{SD} \pm 0.674$ giving a relief of $72 \%$ with ' $t$ ' value $9(\mathrm{p}<0.001)$ which was statistically highly significant. Group III The mean grade of Yellowish colour of urine lowered from 2.4 to 0.4 with $\mathrm{SD} \pm 0.471$ giving a relief of $83.33 \%$ with ' $\mathrm{t}$ ' value $13.41 \quad(p<0.001)$ which was statistically highly significant.

3. Loss of appetite: Group I The mean grade of loss of appetite lowered from the pretrial value of 2.5 to 0.4 with $\mathrm{SD} \pm 0.918$, giving a relief of $72 \%$ with ' $t$ ' value $6.19 \quad(\mathrm{p}<0.001)$ which was statistically highly significant. Group II The mean grade of loss of appetite lowered from the pretrial value of 2.3 to 0.7 with $\mathrm{SD} \pm 0.699$, giving a relief of $69.56 \%$ with ' $t$ ' value $7.23(p<0.001)$ which was statistically highly significant. Group III The mean grade of loss of appetite lowered from the 
pretrial value of 2.6 to 0.2 with $\mathrm{SD} \pm 0.516$, giving a relief of $92.3 \%$ with ' $t$ 'value $14.69(\mathrm{p}<0.001)$ which was statistically highly significant.

4. Abdominal pain: Group I The mean grade of abdominal pain lowered from 0.8 to 0.2 with $\mathrm{SD} \pm$ 0.843 , giving a relief of $75 \%$ with ' $t$ ' value 2.25 ( $>0.02)$ which was statistically not significant. Group II The mean grade of abdominal pain lowered from 1.4 to 0.4 with $\mathrm{SD} \pm 0.816$, giving a relief of $71.42 \%$ with ' $t$ ' value $3.87 \quad(p<0.01)$ which was statistically significant. Group III The mean grade of abdominal pain lowered from 1.33 to 0 with $\mathrm{SD} \pm 0.51$, giving a relief of $100 \%$ with ' $t$ ' value $6.32 \quad(\mathrm{p}<0.001)$ which was statistically highly significant.

5. Nausea/Vomiting: Group I The mean grade of nausea/vomiting lowered from 1.1 to 0.2 with $\mathrm{SD} \pm 0.276$, giving a relief of $81.81 \%$ with ' $\mathrm{t}$ ' value 3.25 ( $\mathrm{p}<0.02)$ which was statistically significant. Group II The mean grade of nausea/vomiting lowered from 1.8 to 0.5 with $\mathrm{SD} \pm 0.674$, giving a relief of $72.22 \%$ with ' $t$ ' value $6.09 \quad(p<0.001)$ which was statistically highly significant. Group III The mean grade of nausea/vomiting lowered from 1.8 to 0.2 with $\mathrm{SD} \pm 0.547$, giving a relief of $88.88 \%$ with ' $\mathrm{t}$ ' value $6.53(\mathrm{p}<0.001)$ which was statistically highly significant.

6. Fever: Group I The mean grade of Fever lowered from 0.8 to 0 with $\mathrm{SD} \pm 1.032$, giving a relief of $100 \%$ with ' $t$ ' value 2.44 ( $p>0.02)$ which was statistically not significant. Group II The mean grade of Fever lowered from 1.1 to 0.4 with $\mathrm{SD} \pm 0.674$, giving a relief of $63.63 \%$ with 't' value $3.27(\mathrm{p}<0.01)$ which was statistically significant. Group III The mean grade of Fever lowered from 1.25 to 0 with $\mathrm{SD} \pm 0.5$, giving a relief of $100 \%$ with ' $t$ ' value $5(\mathrm{p}<0.001)$ which was statistically highly significant.

7. Muscles cramp: Group I The mean grade of muscles cramp from 0.8 to 0 with $\mathrm{SD} \pm 1.032$, giving a relief of $100 \%$ with ' $t$ ' value 2.44 ( $>0.02)$ which was statistically not significant. Group II The mean grade of muscles cramp from 1.1 to 0.3 with $\mathrm{SD} \pm 0.788$, giving a relief of $72.72 \%$ with ' $t$ ' value $3.20(\mathrm{p}<0.02)$ which was statistically significant. Group III The mean grade of muscles cramp from 1.5 to 0 with $\mathrm{SD} \pm 0.707$, giving a relief of $100 \%$ with ' $\mathrm{t}$ ' value $3(\mathrm{p}<0.01)$ which was statistically significant.

8. Itching- Group I The mean grade of itching lowered from 0.2 to 0 with $\mathrm{SD} \pm 0.632$, giving an improvement of $100 \%$ with ' $t$ ' value $1 \quad(p>0.10)$ which was statistically not significant. Group II The mean grade of itching lowered from 1.4 to 0.7 with $\mathrm{SD} \pm 0.674$, giving an improvement of $50 \%$ with ' $t$ ' value $3.27(p<0.01)$ which was statistically significant.

Group III The mean grade of itching lowered from 1 to 0.5 with $\mathrm{SD} \pm 0.577$, giving an improvement of $50 \%$ with ' $t$ ' value $1.7 \quad(\mathrm{p}>0.1)$ which was statistically not significant.

9.Weakness: Group I The mean grade of weakness lowered from 2.6 to 1 with $\mathrm{SD} \pm 0.51$, giving an improvement of $61.53 \%$ with ' $t$ ' value $9.79(\mathrm{p}<0.001)$ which was statistically highly significant. Group II The mean grade of weakness lowered from 1.2 to 0.6 with $\mathrm{SD} \pm 0.699$, giving an improvement of $50 \%$ with ' $t$ ' value $2.71(p>0.02)$ which was statistically not significant. Group III The mean grade of weakness lowered from 2.4to 0.3 with $\mathrm{SD} \pm 0.567$, giving an improvement of $87 \%$ with 't' value $11.69(\mathrm{p}<0.001)$ which was statistically highly significant.

\section{Effect of Laboratory Parameters}

For the diagnosis and assessment of results, the main laboratory criteria were serum bilirubin (B.total) estimation. Group I The mean grade of billirubin total lowered from 2.97 to 1.40 with $\mathrm{SD} \pm 0.955$, giving a relief of $52.93 \%$ with ' $t$ ' value $5.21(\mathrm{p}<0.001)$ which was statistically highly significant. Group II The mean grade of billirubin total lowered from 1.96 to 1.66 with $\mathrm{SD} \pm 0.38$, giving a relief of $15.29 \%$ with' $t$ ' value 2.49 ( $>0.02$ ) which was statistically not significant. Group III The mean grade of billirubin total lowered from 3.869 to 1.131with $\mathrm{SD} \pm 2.01$, giving a relief of $70.76 \%$ with' $t$ ' value 4.29 $(p<0.01)$ which was statistically significant. 


\section{Sides Effects of Therapy}

In the present clinical study, two of the registered patients reported adverse effect of the drug group III (Ghiritkumari and Kakamachi) during the therapy. Two patients reported that after taking these groups III drugs them suffering from heartburn. Haematological investigations carried out before and after the treatment showed no major change. The above findings suggest that there is no systemic ill effect of the drugs Ghiritkumari and Kakamachi. But the Drugs needs to be further evaluated for ill effects on large samples so that the drug can be prescribed for longer duration with complete safety.

\section{Probable Mode of Action}

The present clinical study reveals that Ghritkumari and Kakamachi used are effective in the treatment of Kamala. The results were more appreciable in group III, in both the clinical and laboratory criteria. Statistically, relief in Yellowish color of eyes and urine, loss of appetite, weakness and in reduction in serum bilirubin levels was highly significant. The trial drugs were Ghritkumari and Kakamachi have been used in management of Kamala (Jaundice) in Ayurvedic texts and Nighantus. Experimental studies have shown them to be improves appetite and taste, Moothrala, Yakrituttejaka, moothrala properties. Ghritkumari is Vatahara, Kaphahara and Tridoshhara. Kakamachi is Tridosha Shamak especially kapha shamak. Therefore combination of both the drugs are more significant than individual. Once the doshik homeostasis has been achieved, the signs and symptoms of Kamala are relieved automatically because the disease and its different manifestations are all produced by doshas. Ghritkumari - Ghritkumari is Tikta, Madhur in rasa, Shita Virya. Guru, Snigdha and Pichcchila Guna.It is said of Vatahara, Kaphahara and Tridoshhara shamaka, Bhedana, Krimighana ,Kushthaghan ,Balya,Rasyana, Virecan, Dipan Pacana and Rechana. It is mainly indicated in Pandu, Kamala, Yakritpliha vikaravrddhi, Dourbalaya, Agnidagdha roga etc. Ghritkumari is Tikta, Madhur in Rasa.Katu in Vipak and Guru,
Snigdha, Pichcchila in guna so pacifies Pitta. Pitta is the main factor for Kamala. Ghritkumari is yakrita uttejaka and Artavjanana action. So, clearance of srotodushti which is sanga in case of Kamala. Once the srotodushti is cleared, the vicious cycle of provocation of Pitta, is interrupted and relief in symptoms become evident. Kakamachi: Kakamachi is a Rasayana and it pacifies tridosha. Due to its Tikta Katu rasa, it alleviates Kapha and Pitta, because of Guru, Snigdha and Ushna guna, it normalizes Vata dosha. Other properties of Kakamachi are Yakrit uttejaka, Moothrala, Deepana, Pachana, Pittashamaka, Rechaka, Rakta shodhaka, and Tapakrama. Homeostasis of doshas causes clearance of srotodushti which is sanga in case of Kamala. Once the srotodushti is cleared, the vicious cycle of provocation of Pitta is interrupted and relief in symptoms becomes evident. Being Deepana, it is ama Pachana. Retained metabolic wastes can be compared to ama, therefore Kakamachi is supposed to bring down the Serum billirubin level. From the above description it appears that the drug exerts an effect in breaking the pathogenesis of Kamala. They act as Rasayana, improve Dhatu formation, are Tridoshaghna, Vatashamaka, Raktashodhaka, Pitta sarana and therefore relieve signs and symptoms of Kamala. The Drugs have proved effective in relieving cardinal features of Kamala. As the Drugs have established properties, it may be inferred that the Ghritkumari and Kakamachi are safe and suitable in management of Kamala. Regarding mode of action of Ghritkumari and Kakamachi we have rationally discussed above properties and action which might be responsible to bring changes in sign and symptoms of Kamala. This shows majority of action of the drug are due to Guna prabhava. However, observing the outstanding changes in the condition of patients we have opinion that drug acts certainly by Dravya prabhava also. Therefore we may infer that the action of the Drug in improving the sign and symptoms of Kamala patients by Dravya guna prabhava. 
However, it was a pilot study to evaluate the Gunakarmukta and efficacy of Ghritkumari and Kakamachi in Kamala and it was carried out with help of limited resources. We observed a great potential in the drugs (combined Ghritkumari and Kakamachi) to provide relief in patients of Kamala.

\section{Bibliography}

Books-

1. Pandeya G. Dravya Guna Vijnana, Krishnadas Academy, Varanasi.

2. Yagi A. Aloe Vera 1st Ed., DHC, Tokyo, 1997

3. Frawley D. \& Lad V., The Yoga and Herbs, 1986

4. Fujita K., Aloe Daihyakka, Shufunotomo, Tokyo, 19965. Tanaka K. Medicinal Plant Encyclopedia 1st Ed. Ienohikari

5. kyokai,Tokyo, 2002 Samhita

6. Agnivesha, Dridhabal -Charaka Samhita V5VI Part. Shri Gulabkunvarba Ayurvedic Society, Jamnagar 1st Ed. 1949.

7. Ashtaga Hrdya "Sarvanga Sundara". "Ayurvedic Rasayana" Tikadvaya Krishnadasa Academy, Varanasi.

8. Bhavamishra, Bhavaprakash Samhita, Vidyotini Commentary,Caukhamba Sanskrit Series, Varanasi, 2nd Ed. 1949.

9. Bhela: Bhela Samhita, Caukhamba Sanskrit Series, Varanasi, 1961.

10. Kashyapa: Kashyapa Samhita Ed. Pandit Hemaraja Sharma \& Y.T.Acharya, Nirnaya Sagar Press, Bombay.

11. Sharangadhara: Sharanghadara Samhita Baidyanatha AyurvedaBhavan, 1975.

12. Sushruta Samhita, Ayurveda Tatva Sadipika "Commented by Ambika Dutta Shastry, I5II Part, Caukhamba Sanskrit Bhavan, Varanasi 8th Ed.1993.

Thesis -

13. Singh D.P. 5 Role of certain indigenous drugs on Yuvanapidika in1982, Jamnagar.
14. Agravat H.P5 Yuvanapidika and role of Lodhradi lepa there in 1993 from Jamnagar.

15. Gandhi M. 5 Asthentics in medical science and personality damaging disease particular reference to Yuvanapidika in 1995 from Jamnagar.

16. Web Aloe Vera Company UK, Properties of Aloe Vera Constituents, http://www.aloevera.co.uk/aloeprop.thm1. Aloe Vera Products, http://www.aloeveraproduct.com/about_al oe_vera.htm

17. Herbal Information Center, Aloe Vera,http://www.kcweb.com/herb/aloevera .htm

18. Holistic5 online, Herbal Information, Aloe Vera, http://holisticonline.com/Herbal5Med/_He $\mathrm{rbs} / \mathrm{h} 2 . \mathrm{htm}$

19. Properties and Actions of Aloe Vera,http://www.miyakojima.ne.jp/kyuyou /shoukai.htm

20. Aloe Senka, http://www.wind.ne.jp/hirata/aloesenk.htm Bibliography for Kakamachi (solanum nigram)

21. Amarakosha of Amarasimha.

22. Astanga Sangraham.

23. Astanga Nighantu.

24. Ayurvedic harmacology and therapeutic uses of medicinal plants

25. Vaidhya V.M.Gogte

26. Ayurvedic drugs and their plant sources

27. V.V.Shivaranjan, Indira balachandran.

28. A catalogue of Indian synonyms Modern Sheriff

29. A catalogue of medicinal plants exhibits

30. Bhavaprakasha Nighantu.

31. Charaka Samhita.

32. Chakradatta.

33. Classical uses of medicinal plants 5 Sharma P.V. Prof.

34. Dhanvantari Nighantu 5 Sharma P.V.Prof. \& Dr.Guruprasad

35. Dravya guna Hastamalaka. 
36. Dravya guna Kosha 5 Sharma P.V.Prof.

37. Dravya guna vijnana Vol.II 5 Sharma P.V.Prof.

38. Flora of Coorg [Karnataka] India 5 S.N.Yoganarasimhan

39. Glossary of vegetable drugs in Brahatrayee 5 Takur Balwant Singh \& Dr.K.C.Chunekar 1

40. Hrudayadeepika Nighantu \& Siddhamantra 5 Vaidhyacharya Kesava with prakasha commentary of Vopadeva.

41. Haritakyadi Nighantu

42. Indian material medica Vol.I 5 Dr.K.M.Nadkarni

43. Indian medicinal plants 5 A compendium of 500 species, Orient Longman.

44. Indian medicinal plants Vol.III 5 K.R. Kirthikar \& B.D.Basu

45. Kaiyadeva Nighantu

46. Madapala Nighantu 33

47. Medicinal plants of India Vol.I [Karnataka] 5 S.N.Yoganarasimhan

48. Medicinal plants of India Vol.II [Tamil Nadu]

49. Materia medica of Hindus5 Uday chand dutta

50. Nighantu Adarsha 5 Vaidhya Sri Bapalal

51. Raja Nighantu 5 Tripati Dr.Indradev

52. Sushruta Samhita

53. Shaligrama Nighantu 5 Lal Shastri

54. Sabdakalpa druma

55. Sivakosha of Sivadatta Misra

56. Sarangadara Samhita 5 English commentary

57. Taxonomy of vascular plants 5 George H.M. Lawrence

58. The Wealth of India.

59. Vanoushadi Nidarshika

Bibliography for Kamala roga.

60. Astanga Hridaya (By Pandit Hari Shastri):

Chukhambha Sanskrit Series, Varanasi, 1982.

61. Astanga Sangraha: Chaukhambha Sanskrit Series, Varanasi.
62. Atharv Veda: Translated by Ralpha T.H.Griffith, 2 vol. Chakhambha Sanskrit Series, Varanasi, 1968.

63. Bhava Prakash (Part52 Commented by H.P.Panday, 5 th Ed.): Chaukhambha Sanskrit Sansthan, Varanasi.

64. Bhava Prakash Nighantu: Commented by Chunekar, K.C.and Panday, G.S.(5 th Ed.)Chaukhambha, Varanasi.

65. Bhela Samhita: Chaukhambha Vidyadhawan, Varanasi, 1959.

66. Chakra Datta: Hindi Commentary by Jagdishwar Prasad Tripathi $\left(5^{\text {th }}\right.$ Ed.)C haukhambha, Varanasi.

67. Charaka Samhita: Hindi Commentary by Kashinath Shashtri and G.N.Chaturvedi (11th Ed.), Chaukhambha, Varanasi.

68. Chakrapani: Commentary on Charaka Samhita; 2nd Ed.Nirnaya Sagar Press, Bombay.

69. Concept of Jatharagni and Dhatwagni in Ayurveda: C.C.R.A.S., $1^{\text {st }}$ edition, 1987.

70. Chopra, R.N.: Indian medical plants. Patna University Press, 1932.

71. Dalhana: Dalhana Commentary on Susruta Samhita.Part 1 and 2 C.K.Sen and Company, Calcutta, 1938

72. Davidson, s Principlaes and practice of Medicine, 20 th editions, 2006.

73. Harison, s principle of internal medicine: 12th Ed.15. Human Anatomy: By B.D.Chaurasia.

74. Sushruta Samhita: Commentary by Dr.Ambika Datta Shastri; Chukhambha Sanskrita Sansthan, 1972. 